\title{
Fasciola hepatica in Some Buffaloes and Cattle by PCR and Microscopy
}

\author{
Sultan Ayaz, ${ }^{1}$ Riaz Ullah, ${ }^{2}$ Naser M. AbdEl-Salam, ${ }^{3}$ Sumiara Shams, ${ }^{4}$ and Sadaf Niaz ${ }^{4}$ \\ ${ }^{1}$ College of Veterinary Sciences and Animal Husbandry, Abdul Wali Khan University Mardan, Khyber Pakhtunkhwa 23200, Pakistan \\ ${ }^{2}$ Department of Chemistry, Government College Ara Khel, FR Kohat, Khyber Pakhtunkhwa 26000, Pakistan \\ ${ }^{3}$ Riyadh Community College, King Saud University, Riyadh 11437, Saudi Arabia \\ ${ }^{4}$ Department of Zoology, Abdul Wali Khan University Mardan, Khyber Pakhtunkhwa 23200, Pakistan
}

Correspondence should be addressed to Riaz Ullah; afridiriaz@yahoo.com

Received 30 June 2014; Revised 23 October 2014; Accepted 23 October 2014; Published 13 November 2014

Academic Editor: Rafael Toledo

Copyright (C) 2014 Sultan Ayaz et al. This is an open access article distributed under the Creative Commons Attribution License, which permits unrestricted use, distribution, and reproduction in any medium, provided the original work is properly cited.

\begin{abstract}
Fasciolosis is the burning problem of the livestock rearing community having huge morbidity, mortality, and economic losses to livestock industries in our country Pakistan. The faecal and liver biopsy samplings were examined by polymerase chain reaction (PCR) and microscopy technique during the entire study. A total of 307 samples including 149 samples from Karak and 158 samples from Kohat abattoirs were examined by PCR method and overall prevalence of fasciolosis was 5.86\% (18/307), amongst theses $8.05 \%$ $(12 / 149)$ in liver biopsy and 3.79\% (6/158) in feacal samples of cattle and Buffaloes were recorded. Similarly the microscopy based detection was 3.58\% (11/307) including 4.61\% (7/149) in liver biopsy and 2.5\% (4/158) in faecal samples accordingly. Furthermore the areawise prevalence of fasciolosis in abattoirs by PCR method was found to be $7.59 \%(12 / 158)$ in Kohat and $4.02 \%(6 / 149)$ in Karak. A 618 pb DNA was amplified in 2\% agarose gel electrophoreses. It is concluded from the study that prevalence of fasciolosis was higher in abattoir of district Kohat and PCR was a more sensitive method of diagnosis than microscopy.
\end{abstract}

\section{Introduction}

Fasciolosis in important food born and water born parasitic zoonosis caused by liver fluke of the genus Fasciola $[1,2]$, the F. hepatica, is cosmopolitan in distribution, with high frequency in tropical area [3, 4]. Fasciola spp. may reach the size of $25-30 \mathrm{~mm}$ in length and 8 to $15 \mathrm{~mm}$ width. It has leaf shaped Structure [5]. Fasciola hepatica has an interior and posterior sucker for attachment to host body [6]. Fasciola hepatica completed its entire life cycle in two host cattle, a definitive host, and the snail, an intermediate host, while the human is an accidental host $[1,7]$, which causes disease mostly in ruminants, especially in cattle, buffaloes, sheep, goats, and cow. It may however affect human [8].

These parasites inhabit the hepatobiliary system of the effected animal and rarely can be found in ectopic sites within the host body [9]. Once the parasites eggs are ingested by the cattle by the occasional drinking or grazing, then the parasites migrate through the liver parenchyma to reach the bile duct. The diagnosis of fasciolosis in ruminant caused by Fasciola spp. has been made solely by the detection of Fasciola eggs in the faeces of infected animal [10].

The worldwide losses in animal productivity due to fasciolosis were estimated as US \$200 million per annum to rural agricultural communities and commercial producers with over 600 million animals infected. In developed counties, the incidence of $F$. hepatica can reach up to $77 \%$. In tropical countries, fasciolosis is considered the single most important helminthes infection of cattle, with reported prevalence of $30-90 \%$. In domestic ruminants, adverse effects of acute or chronic fasciolosis include decreased meat and milk production, decreased fertility, and increased veterinary costs [11-13].

Fasciolosis is one of the big and most important worldwide problems mainly due to mortality of animals, cost of diagnosis, and treatment of condemned liver and it reduces milk and meat production, fertility disorder, and drug resistance against fasciolosis [14]. The present research project was designed to carry out the PCR base prevalence of fasciolosis in cattle and buffaloes in abattoir of district Karak and Kohat. 
TABLE 1: Settings of PCR cycle for F. hepatica.

\begin{tabular}{lcccc}
\hline Stage & Cycle & Step & Temperature & Time \\
\hline 1 & 1 & 1 & $92^{\circ} \mathrm{C}$ & $3: 00 \mathrm{~min}$ \\
\hline \multirow{2}{*}{2} & \multirow{2}{*}{25} & 1 & $92^{\circ} \mathrm{C}$ & $40 \mathrm{sec}$ \\
& & 2 & $50^{\circ} \mathrm{C}$ & $40 \mathrm{sec}$ \\
& & 3 & $72^{\circ} \mathrm{C}$ & $1: 00 \mathrm{~min}$ \\
\hline \multirow{2}{*}{3} & 1 & 1 & $92^{\circ} \mathrm{C}$ & $7: 00 \mathrm{~min}$ \\
& & 2 & $92^{\circ} \mathrm{C}$ & Hold \\
\hline
\end{tabular}

\section{Materials and Methods}

2.1. Samples Collection. A total of 307 samples including 158 faecal samples and 149 liver samples were collected from the abattoir of district Kohat and Karak Khyber Pakhtunkhwa from the cattle having different sex and age. Faeces samples were directly collected from the rectum of the cattle in polythene bags which is duly labeled according to sex, age, date, and abattoir from which the samples were collected and similarly the liver samples were collected after slaughtering of those animal which are clinically suspected (having blister or swelling on the liver surfaces) where the faecal samples of the animals were collected. The targeted swelling parts of the liver were incised with scalpel and put in a sterilized bottle duly labeled with date, spp., sex, and breed of the animal. The collected samples were placed in ice jar and were immediately transported to the Virology and Molecular Parasitology Laboratory of the Zoology Department, Kohat University of Science and Technology, Kohat.

2.2. Microscopy. Thick and thin smears were prepared from the faecal and liver biopsy including bile duct material. Both of faeces and liver biopsy were mixed with buffer saline and a drop of $20 \mu \mathrm{L}$ was placed on the slides and dried and were puts a drop of immersion oil and then observed under the direct microscopy of 10x, 40x, and 100x. The images were compared with the standard morphological size.

2.3. DNA Extraction. The samples were subjected to DNA extraction by using GF-1 kit (vivantis) as per the manufacturer protocol (Sultan Ayaz PhD thesis, 2009 HEC Pakistan panel). A $200 \mu \mathrm{L}$ liver biopsy as well as the faecal pellet samples in Eppendorf tube was mixed with $50 \mu \mathrm{L}$ of proteinase $\mathrm{K}$ and $200 \mu \mathrm{L}$ of buffer VL. They were mixed well with the help of vertex and then were incubated at $65^{\circ} \mathrm{C}$ for $10 \mathrm{~min}$ in hot plates. The columns were centrifuged at $6000 \mathrm{rpm}$ for $1 \mathrm{~min}$ and the flow through was discarded; then $200 \mu \mathrm{L}$ of wash buffer was added and centrifuged at $6000 \mathrm{rpm}$ for $1 \mathrm{~min}$ and again the supernatant was discarded. Similarly $200 \mu \mathrm{L}$ of wash buffer 2 was added and centrifuged at $6000 \mathrm{rpm}$ for $1 \mathrm{~min}$ and supernatant was discarded. Then the columns were transferred to new tubes and $30 \mu \mathrm{L}$ of elution buffer was added and placed for $2 \mathrm{~min}$ at room temperature. After that centrifugation was at $6000 \mathrm{rpm}$ for $1 \mathrm{~min}$ and was mixed with $30 \mu \mathrm{L}$ of deionized water and stored at $-80^{\circ} \mathrm{C}$ for further process.

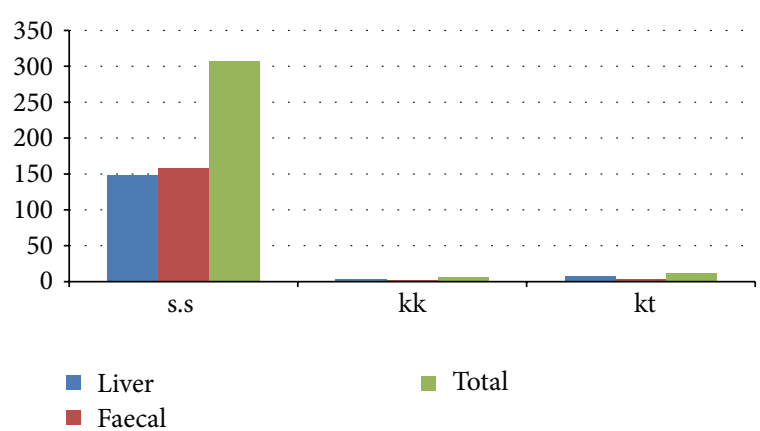

FIGURE 1: Prevalence of fasciolosis cattle and buffaloes by using PCR and microscopy methods in Karak and Kohat, Pakistan.

2.4. DNA Amplification (PCR). The DNA was amplified through polymerase chain reaction (PCR) using primer specific for Fasciola hepatica (Figure 2). The primer added for $F$. hepatica was -F, 5'-AGTGATTACCCGCTGAACT$3^{\prime}$, and R, $3^{\prime}$-CTGAGAAAGTGCACTGACAA-5' [13]. The specific amplified product was compared with $100 \mathrm{bp}$ DNA ladder marker (Fermentas, USA). The parasitic DNA was recognized.

The target DNA was amplified in $20 \mu \mathrm{L}$ reaction mixture containing 10x PCR buffer $2 \mu \mathrm{M}, 1 \mu \mathrm{M}$ deoxynucleoside triphosphate $(500 \mu \mathrm{M}), 2.4 \mu \mathrm{M} \mathrm{MgCl}_{2}(25 \mu \mathrm{m}) 1 \mu \mathrm{M}$ primers (10 pmol), target DNA $5 \mu \mathrm{L}$, and 0.3 unit of Taq DNA polymerase $(5 \mathrm{u} / \mu \mathrm{L})$; add deionized water up to $20 \mu \mathrm{L}$. Denaturing of DNA amplification was done at temperature $\left(92^{\circ} \mathrm{C}\right.$ for $3 \mathrm{~min}, 25$ cycles $),\left(92^{\circ} \mathrm{C}\right.$ for $\left.40 \mathrm{sec}\right),\left(50^{\circ} \mathrm{C}\right.$ for $\left.40 \mathrm{sec}\right)$, and $\left(72^{\circ} \mathrm{C}\right.$ for $\left.60 \mathrm{sec}\right)$. In the last stage extension at $72^{\circ} \mathrm{C}$ for $7 \mathrm{~min}$ and hold at $4^{\circ} \mathrm{C}$ for unlimited time (Table 1 ), the designed program was saved.

2.5. Gel Electrophoresis. In gel electrophoresis, $2 \mathrm{~g}$ of Agarose was added in $100 \mathrm{~mL}$ of TBE buffer and placed in oven for 2 minutes at $100^{\circ} \mathrm{C}$. Then removed this mixture and cool down it up to $45^{\circ} \mathrm{C}$ after then added $20 \mu \mathrm{L}$ of ethidium bromide. The gel was poured into gel tray and combs were fixed. Combs were removed after gel was formed. So by this way, the Gel tray was placed in gel tank containing $1000 \mathrm{~mL} 0.5 \mathrm{x}$ TBE buffer. $10 \mu \mathrm{L}$ Of PCR product was mixed with $5 \mu \mathrm{L}$ of bromophenol blue dye of each sample was loaded in the wells and $15 \mu \mathrm{L}$ of DNA ladder (100 bp) was loaded in the separate well. The positive and negative control was run parallel with the samples. The gel was run for $25 \mathrm{~min}$ at voltage of 130 volts and 500 ampere current. Gel was then examined by UV transilluminator. A photo was cached and saved in a record.

\section{Results and Discussion}

Fasciolosis is a very serious disease, having huge economic losses of the cattle and industries in terms of meat, milk, and leather in our country. In the current study a total of 307 samples were examined, which included 149 samples from Karak and 158 samples from Kohat of the cattle and buffalos of Khyber Pakhtunkhwa. By examination it is shown that the overall prevalence of fasciolosis was $5.86 \%$ (18/307), amongst 
TABLE 2: Prevalence of fasciolosis in cattle and buffaloes in district abattoirs of Karak and Kohat by using PCR and microscopy methods.

\begin{tabular}{lccccc}
\hline Sample & $\begin{array}{c}\text { Spp. } \\
\text { cattle + buffaloes } \\
\text { from Karak + Kohat }\end{array}$ & $\begin{array}{c}\text { Karak } \\
\text { PCR positive } \\
\text { (cattle + buffaloes) } \%\end{array}$ & $\begin{array}{c}\text { Kohat } \\
\text { PCR positive } \\
\text { (cattle + buffaloes) } \%\end{array}$ & $\begin{array}{c}\text { Prevalence } \\
\text { (PCR) } \\
\%\end{array}$ & $\begin{array}{c}\text { Microscopy } \\
\text { prevalence } \\
\%\end{array}$ \\
\hline Liver sample & $70+79=149$ & 4 & 8 & $4+8=12$ & $7 / 149$ \\
& & $5.71 \%(4 / 70)$ & $10.12 \%(8 / 79)$ & $8.05 \%(12 / 149)$ & $4.6 \%$ \\
\hline \multirow{2}{*}{ Faecal sample } & $79+79=158$ & $2.53 \%(2 / 79)$ & $5.06 \%(4 / 79)$ & $3.79 \%(6 / 158)$ & $2.5 \%$ \\
\hline \multirow{2}{*}{ G. total } & $149+148=307$ & $4+2=6$ & $8+4=12$ & $6+12=18$ & $11 / 307$ \\
& & $4.02 \%(6 / 149)$ & $7.59 \%(12 / 158)$ & $5.86 \%(18 / 307)$ & $3.58 \%$ \\
\hline
\end{tabular}

TABLE 3: PCR based detection of fasciolosis in the district abattoir of Kohat.

\begin{tabular}{|c|c|c|c|c|c|c|c|c|c|c|}
\hline \multirow{2}{*}{ Sample } & \multicolumn{2}{|c|}{ Cow } & \multicolumn{2}{|c|}{ Buffalo } & \multicolumn{2}{|c|}{ Total sample } & \multicolumn{2}{|c|}{ Prevalence \% } & \multirow{2}{*}{$\begin{array}{c}\text { Total } \\
\text { prevalence \% }\end{array}$} & \multirow[b]{2}{*}{ Other findings } \\
\hline & $\begin{array}{l}\text { Positive } \\
\text { sample }\end{array}$ & $\begin{array}{l}\text { Negative } \\
\text { sample }\end{array}$ & $\begin{array}{l}\text { Positive } \\
\text { sample }\end{array}$ & $\begin{array}{l}\text { Negative } \\
\text { sample }\end{array}$ & Cow & Buffaloes & Cow & Buffalo & & \\
\hline $\begin{array}{l}\text { Faecal } \\
\text { sample }\end{array}$ & 1 & 38 & 3 & 37 & 39 & 40 & $\begin{array}{l}2.56 \% \\
(1 / 39)\end{array}$ & $\begin{array}{c}7.5 \% \\
(3 / 40)\end{array}$ & $5.06 \%(4 / 79)$ & $\begin{array}{c}\text { E. histolytica } \\
\text { and } \\
\text { G. lamblia } \\
\text { cryptosporidium }\end{array}$ \\
\hline $\begin{array}{l}\text { Liver } \\
\text { sample }\end{array}$ & 3 & 35 & 5 & 36 & 38 & 41 & $\begin{array}{l}8.33 \% \\
(3 / 38) \\
\end{array}$ & $\begin{array}{c}12.19 \% \\
(5 / 41)\end{array}$ & $10.12 \%(8 / 79)$ & No other findings \\
\hline G. total & 4 & 73 & 8 & 76 & 77 & 81 & $\begin{array}{l}5.19 \% \\
(4 / 77)\end{array}$ & $\begin{array}{c}9.8 \% \\
(8 / 81)\end{array}$ & $7.59 \%(12 / 158)$ & $\begin{array}{c}\text { E. histolytica } \\
\text { and } \\
\text { G. lamblia } \\
\text { cryptosporidium }\end{array}$ \\
\hline
\end{tabular}

TABLE 4: PCR based detection of fasciolosis in the district abattoir of Karak.

\begin{tabular}{|c|c|c|c|c|c|c|c|c|c|c|}
\hline \multirow[b]{2}{*}{ Sample } & \multicolumn{2}{|c|}{ Cow } & \multicolumn{2}{|c|}{ Buffalo } & \multicolumn{2}{|c|}{ Total sample } & \multicolumn{2}{|c|}{ Prevalence \% } & \multirow{2}{*}{$\begin{array}{c}\text { Total } \\
\text { prevalence \% }\end{array}$} & \multirow[b]{2}{*}{ Other findings } \\
\hline & $\begin{array}{l}\text { Positive } \\
\text { sample }\end{array}$ & $\begin{array}{c}\text { Negative } \\
\text { sample }\end{array}$ & $\begin{array}{l}\text { Positive } \\
\text { sample }\end{array}$ & $\begin{array}{c}\text { Negative } \\
\text { sample }\end{array}$ & Cow & Buffaloes & Cow & Buffalo & & \\
\hline $\begin{array}{l}\text { Faecal } \\
\text { sample }\end{array}$ & 1 & 39 & 1 & 38 & 40 & 39 & $\begin{array}{l}2.5 \% \\
(1 / 40)\end{array}$ & $\begin{array}{l}2.56 \% \\
(1 / 39)\end{array}$ & $2.53 \%(2 / 79)$ & $\begin{array}{c}\text { E. histolytica } \\
\text { and } \\
\text { G. lamblia } \\
\text { cryptosporidium }\end{array}$ \\
\hline $\begin{array}{l}\text { Liver } \\
\text { sample }\end{array}$ & 1 & 24 & 3 & 42 & 25 & 45 & $\begin{array}{c}4 \% \\
(1 / 25) \\
\end{array}$ & $\begin{array}{l}6.66 \% \\
(3 / 45) \\
\end{array}$ & $5.71 \%(4 / 70)$ & No other findings \\
\hline G. total & 2 & 63 & 4 & 80 & 65 & 84 & $\begin{array}{l}3.07 \% \\
(2 / 65)\end{array}$ & $\begin{array}{l}4.76 \% \\
(4 / 84)\end{array}$ & $4.02 \%(6 / 149)$ & $\begin{array}{c}\text { E. histolytica } \\
\text { and } \\
\text { G. lamblia } \\
\text { cryptosporidium }\end{array}$ \\
\hline
\end{tabular}

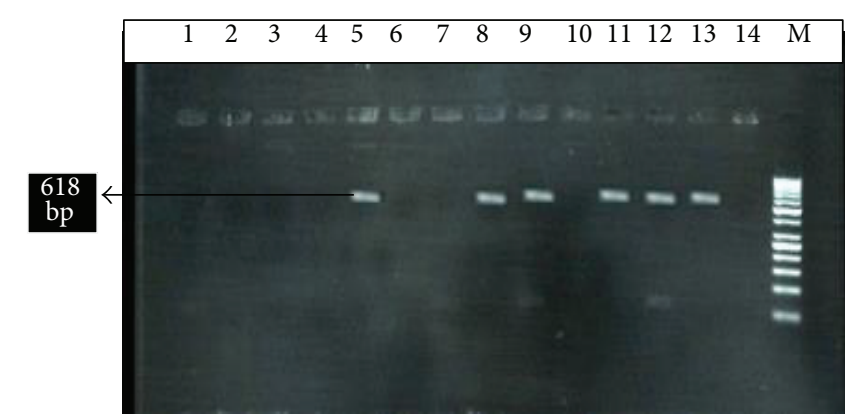

FIGURE 2: M; 100 bp DNA ladder, lane 5 is positive control, while lane 14 is negative control. Lanes 13, 12, 11, 9, and 8 are positive and the other lanes $1,2,3,4,6,7$, and 10 are negative. The amplified DNA band showing $618 \mathrm{bp}$. 
these $4.02 \%$ (6/149) in the district Karak and 7.5\% (12/158) in the district Kohat. Furthermore the prevalence of Fasciolosis in cows was $3.07 \%(2 / 65)$ and $4.76 \%(4 / 84)$ in the Buffaloes of the district Karak was recorded while 5.19\% (4/77) in the Cow and 9.87\% (8/81) in the Buffaloes of district Kohat of the Khyber Pakhtunkhwa were recorded. The prevalence of fasciolosis was higher in district Kohat as compared to district Karak. Statistical analysis revealed the significant difference $P<0.05$ when the data was interpreted (Tables 2, 3, and 4) (Figure 1).

In the present study, F. hepatica was found in the fecal sample and liver biopsy sample of cows and buffaloes in the abattoir of the district Karak and Kohat of the Khyber Pakhtunkhwa province of Pakistan.

One of the studies revealed that it was the disease of domesticated animals in Sindh province that causes heavy infection of $F$. hepatica. Moreover, F. gigantica was reported at high altitudes in Khyber Pakhtunkhwa province, whereas F. hepatica occurred in deltaic region of Punjab and Sindh provinces, Pakistan. Similar, findings were previously reported In Faisalabad (central Punjab) [15]; overall prevalence of fasciolosis was found to be $17.55 \%$, of which $F$. hepatica was $5.7 \%$. However mixed infection was revealed in $2.02 \%$ animals [16].

Fasciola hepatica was the dominant fluke species in the animals [17]. This may be associated with the existence of favorable ecological biotopes for Lymnaea truncatula, the recognized intermediate host of $F$. hepatica in Ethiopia [18].

The worldwide losses in animal productivity due to fasciolosis were estimated at US $\$ 200$ million per annum to rural agricultural communities and commercial producers [19], with over 600 million animals infected [20]. In developed counties, the incidence of $F$. hepatica can reach up to $77 \%$. In tropical countries, fasciolosis is considered the single most important helminthes infection of cattle, with reported prevalence of $30-90 \%$ [21]. This study coincided partially with our study in cattle and buffaloes.

Similar study from Northern Iran (Tonekabon) indicates a $15 \%$ prevalence of fasciolosis in buffaloes and $4.6 \%$ in cattle [22]. Fasciolosis is now recognized as an emerging food born zoonosis in many parts of the world and world health organization has also included human fasciolosis on its list [23].

\section{Conflict of Interests}

The authors declared that there is no conflict of interests regarding the publication of this paper.

\section{Acknowledgment}

The authors are thankful to the Deanship of Scientific Research, King Saud University, Riyadh, for funding the work through the research group Project no. RGP-210.

\section{References}

[1] S. Mas-Coma, M. D. Bargues, and M. A. Valero, "Fascioliasis and other plant-borne trematode zoonoses," International Journal for Parasitology, vol. 35, no. 11-12, pp. 1255-1278, 2005.
[2] P. Zhou, N. Chen, R.-L. Zhang, R.-Q. Lin, and X.-Q. Zhu, "Foodborne parasitic zoonoses in China: perspective for control," Trends in Parasitology, vol. 24, no. 4, pp. 190-196, 2008.

[3] M. S. Mas-Coma, J. G. Esteban, and M. D. Bargues, "Epidemiology of human fascioliasis: a review and proposed new classification," Bulletin of the World Health Organization, vol. 77, no. 4, pp. 340-346, 1999.

[4] T. W. Spithill and J. P. Dalton, "Progress in development of liver fluke vaccines," Parasitology Today, vol. 14, no. 6, pp. 224-228, 1998.

[5] S. J. Andrews, The Life Cycles of Fasciola hepatica, edited by J. P. Dalton, CAB International, Oxon, UK, 1999.

[6] A. M. Dunn, Veterinary Helminthology, Butler and Tanner, London, UK, 2nd edition, 1978.

[7] J. L. Vaughan, J. A. Charles, and J. C. Boray, "Fasciola hepatica infection in farmed emus (Dromaius novaehollandiae)," Australian Veterinary Journal, vol. 75, no. 11, pp. 811-813, 1997.

[8] H. Alcaino, "Epidemiology of fasciolasis in chile," in Basic Research in Helminthiasis, R. Ehrlich, A. Nieto, and L. Yarzabal, Eds., pp. 11-30, Ediciones Logos, Montevideo, Uruguay, 1990.

[9] T. G. T. Nguyen, N. van de, J. Vercruysse, P. Dorny, and T. H. Le, "Genotypic characterization and species identification of Fasciola spp. with implications regarding the isolates infecting goats in Vietnam," Experimental Parasitology, vol. 123, no. 4, pp. 354-361, 2009.

[10] S. J. Andrews, "The life cycle of Fasciola hepatica," in Fasciolosis, J. P. Dalton, Ed., pp. 1-2, CABI Publishing, Oxin, UK, 1999.

[11] G. Theodoropoulos, E. Theodoropoulou, G. Petrakos, V. Kantzoura, and J. Kostopoulos, "Abattoir condemnation due to parasitic infections and its economic implications in the region of Trikala, Greece," Journal of Veterinary Medicine, vol. 49, no. 6, pp. 281-284, 2002.

[12] E. S. Swai and E. Ulicky, "An evaluation of the economic losses resulting from condemnation of cattle livers and loss of carcass weight due to Fasciolosis: a case study from Hai town abattoir, Kilimanjaro region, Tanzania," Livestock Research for Rural Development, vol. 21, no. 11, 2009.

[13] I. Khan, A. M. Khan, S. Ayaz, S. Khan, M. Anees, and S. A. Khan, "Molecular detection of Fasciola hepatica in water sources of District Nowshehra Khyber Pakhtunkhwa Pakistan," International Journal of Advancements in Research \& Technology, vol. 1, no. 7, pp. 1-11, 2012.

[14] J. Keiser and J. Utzinger, "Food-borne trematodiasis: current chemotherapy and advances with artemisinins and synthetic trioxolanes," Trends in Parasitology, vol. 23, no. 11, pp. 555-562, 2007.

[15] S. B. Kendall, "Fasciolosis in Pakistan," Annals of Tropical Medicine and Parasitology, vol. 48, pp. 307-313, 1954.

[16] C. S. Hayat, Z. Iqbal, B. Hayat, and M. N. Khan, "Studies on the seasonal prevalence of fasciolosis and lungworm disease in sheep at Faisalabad," Pakistan Vaternary Journal, vol. 6, no. 3, p. 131, 1986.

[17] M. Graber and P. Daynes, "Mollusques vecteurs de trématodoses humaines et animals en Ethiopie," Revue d'Élevage et de Médecine Vétérinaire des Pays Tropicaux, vol. 27, no. 3, pp. 307-322, 1974.

[18] J. C. Boray, "Flukes of domestic animals," in Parasites, Pests and Predators, S. M. Gaafar, W. S. Howard, and R. E. Marsh, Eds., pp. 178-218, Elsevier, New York, NY, USA, 1985. 
[19] V. Ramajo, A. Oleaga, P. Casanueva, G. V. Hillyer, and A. Muro, "Vaccination of sheep against Fasciola hepatica with homologous fatty acid binding proteins," Veterinary Parasitology, vol. 97, no. 1, pp. 35-46, 2001.

[20] T. W. Spithill, P. M. Smooker, and D. B. Copeman, "Fasciola gigantica: epidemiology, control, immunology and molecular biology," in Fasciolosis, J. P. Dalton, Ed., 1999.

[21] A. M. Phiri, I. K. Phiri, C. S. Sikasunge, and J. Monrad, "Prevalence of fasciolosis in Zambian cattle observed at selected abattoirs with emphasis on age, sex and origin," Journal of Veterinary Medicine Series B, vol. 52, no. 9, pp. 414-416, 2005.

[22] A. Freites, C. Colmenares, B. Alarcón-Noya, M. E. García, and O. Díaz-Suárez, "Human fasciolosis in Mara municipality, Zulia state. Venezuela: prevalence and asociated factors," Investigacion Clinica, vol. 50, no. 4, pp. 497-506, 2009.

[23] World Health Organization, Fact Sheet on Fasciolosis. Action Against Worms, vol. 10, World Health Organization Headquarters, Geneva, Switzerland, 2008. 

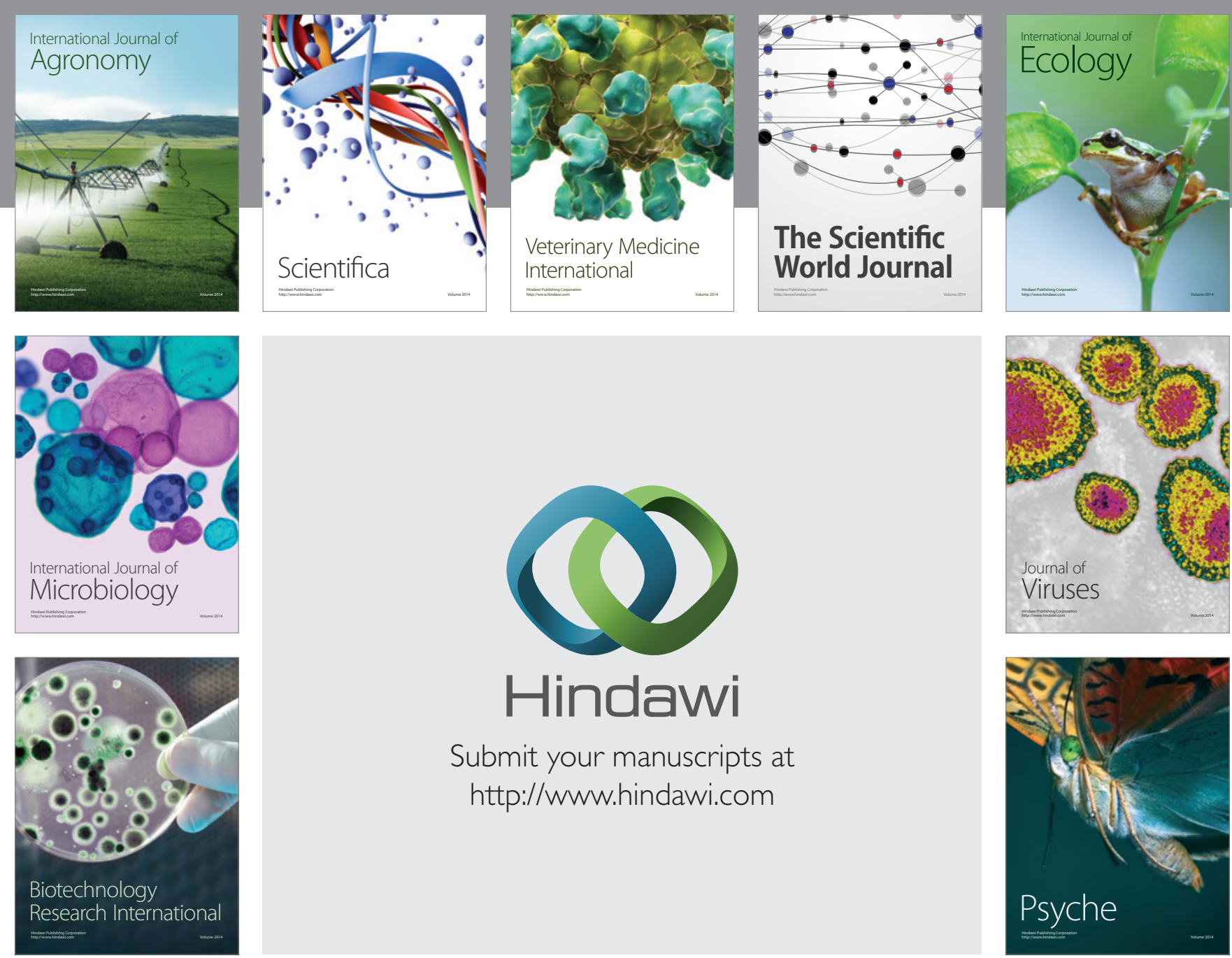

Submit your manuscripts at http://www.hindawi.com
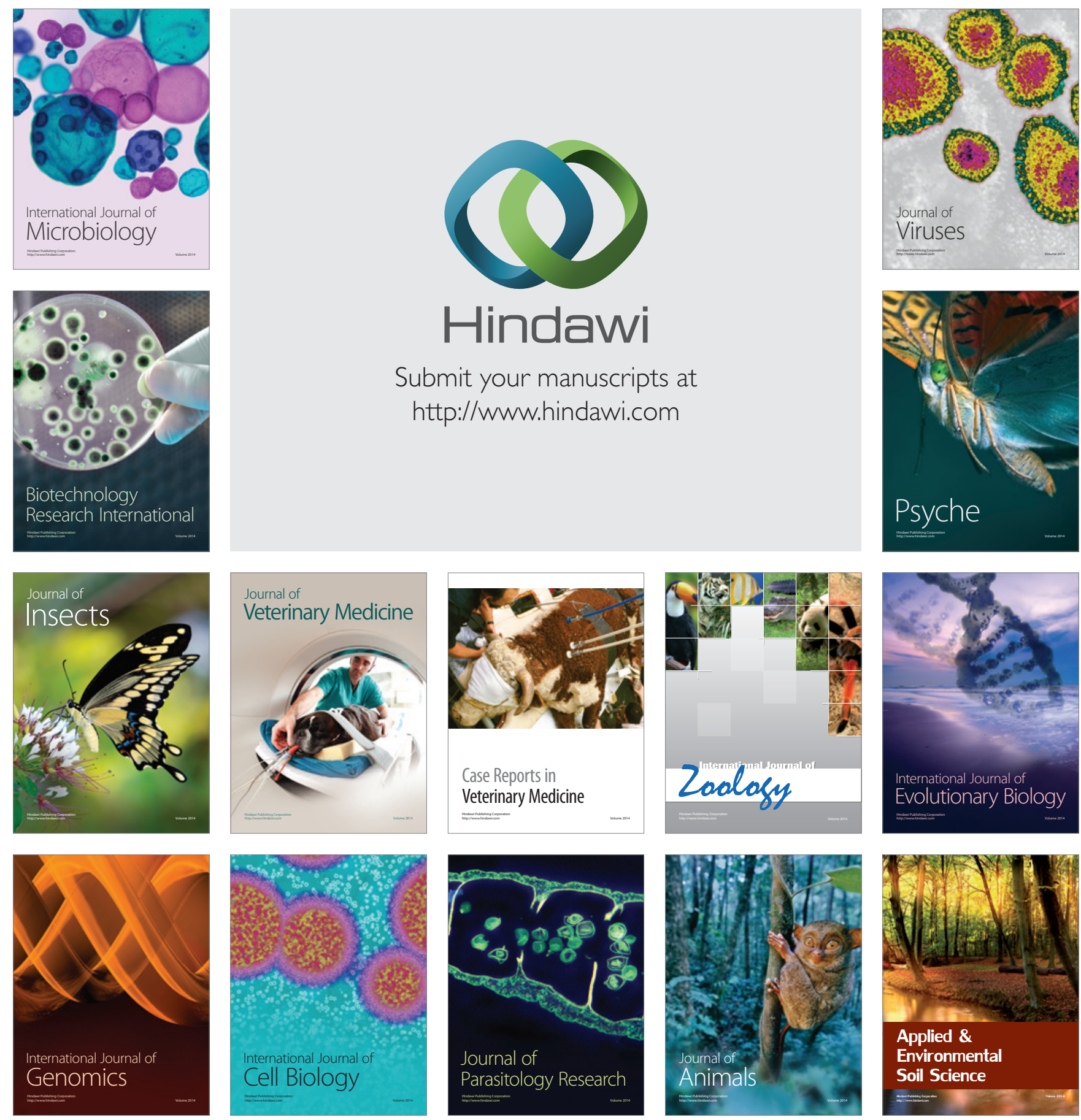